\title{
Pengaruh Online Customer Review dan Tagline Terhadap Keputusan Pembelian Produk Fashion Di Marketplace Shopee dengan Minat Beli SebagaI Variabel Intervening: Studi Pada Generasi Muda Surabaya
}

\author{
Noky Ananda Haniscara, Saino \\ Universitas Negeri Surabaya, Surabaya, Indonesia \\ Email authors: noky.17080324065@mhs.unesa.ac.id/saino@unesa.ac.id
}

\begin{abstract}
ABSTRAK
Penelitian ini bertujuan untuk menjelaskan dan menganalisis pengaruh online customer review dan tagline terhadap keputusan pembelian produk fashion di marketplace Shopee dengan minat beli sebagai variabel intervening. Populasi pada penelitian ini adalah generasi muda Surabaya pengguna Shopee berjenis kelamin perempuan dan laki - laki. Penelitian ini berjenis deskriptif kuantitatif untuk teknik pengambilan sampelnya menggunakan purposive random sampling dengan responden berjumlah 100 generasi muda Surabaya yang merupakan pengguna Shopee. Sumber data menggunakan data primer berupa angket online melalui google form.Teknik analisis yang digunakan adalah analisis jalur (analysis path), uji f dan koefisien determinasi, serta uji hipotesis (uji t) dengan menggunakan SPSS versi 25.
\end{abstract}

Kata Kunci : online customer review, tagline, minat beli, keputusan pembelian.

\section{PENDAHULUAN}

Kemajuan teknologi tidak dapat dipungkiri dan diragukan lagi. Hal tersebut terlihat jelas pada aktivitas manusia yang tidak luput dari handphone, laptop, dan berbagai teknologi komunikasi lainnya. Dengan perkembangan teknologi tersebut menyebabkan perubahan perilaku konsumen yang awalnya berbelanja melalui offline shop berubah menjadi berbelanja melalui online shop. Dita dkk (2018) menyatakan bahwa banyak orang yang memiliki kebiasaan berbelanja online karena kemudahan sistem berbelanja yang diberikan. Menurut Saputri (2016) perilaku belanja dipengaruhi dengan beberapa faktor yakni faktor budaya, sosial, psikologis yang dapat menimbulkan keputusan belanja.

Pada situs resmi cermati.com yang membahas mengenai perubahan gaya belanja masyarakat, fenomena belanja online semakin pesat, Bank Indonesia memperkirakan sebanyak 24,7 individu berbelanja melalui online. Indonesia merupakan negera berkembang, maka berdampak pula pada pengguna internet yang semakin tahun semakin meningkat. Dilihat dari data yang diperoleh dari validnews.id, pengguna internet tahun 2020 di Indonesia mengalami pertumbuhan dibandingkan tahun 2019.

Pengguna internet di Indonesia pada tahun 2020 tumbuh sebesar 4,6\% atau sekitar 15 juta pengguna jika dibandingkan dengan tahun 2019. Dengan pertumbuhan pengguna internet tersebut, pasar konvensional telah digeser dengan sistem sistem belanja online yang saat ini digemari. Berawal dari munculnya beberapa aplikasi e- commerce yang menjadi salah satu tempat untuk menawarkan produk serta jual beli online. Menurut Traver (2017) $e$ - commerce adalah suatu sistem jual beli dengan menggunakan teknologi internet dan melakukan pertukaran nilai antar individu. Pangsa pasar pada aplikasi belanja online tidak hanya satu kalangan saja, melainkan hampir setiap individu telah mengenal dan menggunakan aplikasi belanja online. Generasi muda atau biasa disebut gen $\mathrm{Z}$ yang hampir setiap hari menggunakan gadget menjadi salah satu pengguna aplikasi belanja online. Generasi muda atau gen $\mathrm{Z}$ merupakan generasi yang lahir sekitar tahun 1997 hingga taun 2000-an, generasi muda dinilai 
dengan generasi yang ambisius serta mahir tentang hal digital (kompas.com). Menurut UU kepemudaan no 40 tahun 2009 yang dikutip dari artikel tribunnews.com berisi batasan usia pemuda Indonesia yakni umur 15 - 30 tahun yang dianggap sudah mampu melakukan kegiatan belanja online dengan baik.

Saat ini telah banyak bermunculan aplikasi belanja online yang diminati seperti Shopee, Lazada, Tokpedia, dll. Salah satu media bisnis online atau $e$-commerce terdapat di Indonesia yaitu Shopee. Pada web resmi databoks.katadata.co.id di Indonesia tahun 2020, Shopee merupakan $e$-commerce yang paling banyak digunakan yang ditunjukkan dengan jumlah sebesar 71,5 juta pengguna. Shopee mendapatkan posisi pertama mengalahkan tokopedia yang berada di bawahnya dengan jumlah pengguna 69,8 juta pengguna.

Beberapa keunggulan yang dimiliki Shopee yakni adanya fitur gratis ongkos kirim, terdapat program yang menarik, proses pembayarannya yang mudah, bersifat transparan karena konsumen bisa cek resi shopee dengan mudah. Shopee memiliki berbagai kategori produk yang diperjual belikan yang salah satunya merupakan produk fashion. Konsumen dimudahkan dengan pengelompokkan kategori yang sudah tersedia sehingga konsumen dapat langsung memilih kategori yang dibutuhkan dan akan muncul produk dari beberapa toko dengan rating penilaian yang berbeda - beda. Shopee dapat memudahkan pembeli dalam berbelanja produk yang mereka inginkan tanpa harus pergi kemana - mana, shopee memiliki berbagai macam produk yang dijual dan juga terdapat diskon maupun voucher gratis ongkir.

Salah satu fitur yang paling digemari konsumen adalah fitur gratis ongkir yang juga andalan atau bagian dari tagline Shopee. Shopee menerapkan sistem gratis ongkir pada waktu tertentu seperti pada bulan yang memiliki tanggal sama dengan contoh 12.12. Pada event 12.12 Shopee melakukan diskon besar - besaran dan juga merupakan hari belanja nasional pada akhir tahun. Shopee menyediakan voucher gratis ongkir (subsisdi ongkos kirim) pada setiap pembelian dengan jumlah minimum tertentu.

Pada penelitian ini variabel yang digunakan adalah online customer review, tagline terhadap keputusan pembelian yang dimediasi dengan minat beli. Online customer review merupakan sebuah ulasan yang berisi informasi dan evaluasi terhadap suatu produk tertentu mengenai berbagi aspek yang kemudian informasi tersebut dapat digunakan konsumen untuk mengetahui kualitas yang diinginkan berdasarkan evaluasi konsumen sebelumnya (Mo \& Fan, 2015). Konsumen membandingkan antara online customer review yang satu dengan yang lainnya ketika akan membeli suatu produk. Dalam online customer review, konsumen dapat memberikan komentar negatif maupun positif tentang produk pada toko. Dalam penelitian milik Putri dan Wandebori (2016) indikator online customer review yaitu manfaat yang dirasakan, kualitas argumen, kredibilitas sumber, jumlah ulasan, valensi.

Online customer review diduga memberikan dampak pada minat beli. Pada penelitian milik Farki (2016) didapatkan hasil online customer review memiliki pengaruh secara signifikan pada minat beli. Sehingga jika online customer review pada marketplace baik maka diikuti dengan minat beli pada konsumen.

\section{H1 Diduga terdapat pengaruh online consumer review terhadap minat beli pada produk fashion di marketplace Shopee}

Tagline merupakan rangkaian kata - kata yang disusun secara ekspresif yang bertujuan untuk mengkomunikasikan dan membujuk audiens terhadap suatu brand tertentu (Knapp dalam Chaidir, 2018). Menurut Abiromo dan Wibowo (2014) tagline merupakan kalimat singkat namun memiliki pesan yang bermakna sehingga mudah diingat oleh masyarakat. Pada penelitian ini, indikator tagline megacu pada teori Callen Barry (dalam Dhani 2019) tagline yakni Familiarity, Differentiation, Messager of value. Penelitian milik Dhani (2019) didapatkan hasil tagline berpengaruh secara signifikan terhadap minat beli. 


\section{H2 Diduga terdapat pengaruh tagline terhadap minat beli pada produk fashion di marketplace Shopee}

Minat beli merupakan perilaku yang ditunjukkan dilakukan konsumen yang mana timbul hasrat atau keinginan untuk memilih atau membeli suatu produk berdasarkan pengalaman (Kotler dan Keller, 2006). Sedangkan menurut (Schiffman dan Kanuk, 2015) minat beli merupakan sikap seseorang terhadap penilaian suatu produk, jasa maupun yang lainnya dan menimbulkan keinginan untuk membeli.

Minat beli akan terbentuk karena terdapat kepercayaan konsumen terhadap kualitas suatu produk dan apabila kualitas produk semakin rendah maka diikuti dengan semakin rendahnya minat beli pada konsumen Penitasari (2017). Menurut Fradipta (2017) minat beli adalah suatu rasa ketertarikan yang dipengaruhi oleh sikap internal maupun eksternal pada calon pelanggan dalam memilih suatu produk. Minat beli memiliki pengaruh terhadap keputusan pembelian, hal tersebut sejalan dengan hasil penelitian milik Ady (2019) yang menghasilkan variabel minat beli memiliki pengaruh terhadap keputusan pembelian. Pada penelitian ini, indikator minat beli diukur dengan menggunakan teori Ferdinand dalam Sinaga (2018) yaitu minat transaksional, referensial, preferensial, eksploratif.

Tjiptono (2015) keputusan pembelian merupakan pemecahan suatu masalah yang terjadi pada suau individu atau kelompok yang dimulai dengan mencari informasi terlebih dahulu menganai produk yang akan digunakan sebelum memutuskan untuk melakukan keputusan pembelian. Menurut Deveaj et. al. (dalam Suhari, 2008) serta Murwatiningsih dan Apriliani (2013) indikator keputusan pembelian adalah pilihan produk, efisiensi pencarian, interaksi yang merupakan kemanan dan navigasi, waktu pembelian, metode pembayaran.

H3 Diduga terdapat pengaruh minat beli terhadap keputsan pembelian pada produk fashion di marketplace Shopee

Online customer review atau dapat dikatakan dengan word of mouth yang memberikan kebebasan beropini terhadap suatu produk yang mengakibatkan konsumen memiliki banyak informasi mengenai produk tersebut dan akan menimbulkan kebingungan untuk memutuskan keputusan pembelian (Wang et al., 2015). Online customer review berpengaruh terhadap keputusan pembelian. Pernyataan tersebut sesuai dengan penelitian milik (Nieto et al., 2014) yang menghasilkan online customer reviewberpengaruh signifikan terhadap keputusan pembelian. Namun berbeda pula pada penelitian milik Wang et al (2015) yang memiliki hasil berbeda yakni online customer review tidak memiliki pengaruh secara signifikan terhadap keputusan pembelian.

\section{H4 Diduga terdapat pengaruh online customer review terhadap keputusan pembelian pada produk fashion di marketplace Shopee}

Berdasarkan penelitian sebelumnya yang telah dilakukan oleh Vani (2019) didapatkan hasil tagline memiliki pengaruh signifikan pada keputusan pembelian berbelanja online. Dalam penelitian milik Fakhrurrozi (2016) keputusan pembelian online dipengaruhi oleh beberapa faktor yaitu : (1) keputusan membeli konsumen secara online yang meliputi karakteristik konsumen, lingkungan, karakteristik produk. (2) keputusan membeli konsumen yang meliputi maksudpembelian. (3) karakteristik konsumen yang meliputi gender, umur,dll. (4) karakteristik lingkungan yang meliputi sosial, budaya. (5) karakteristik penjual yang meliputi reputasi, kepercayaan. (6) karakter produk yang meliputi pengetahuan mengenai produk, frekuensi pembelian, harga. 
H5 Diduga terdapat pengaruh tagline terhadap keputusan pembelian pada produk fashion di marketplace Shopee

Dalam membeli suatu produk, konsumen biasanya mencari informasi mengenai spesifikasi, kelebihan, maupun kelemahan produk yang ingin dibeli sebelum melakukan keputusan pembelian. Dengan perkembangan internet, online customer review menjadi bahan pertimbangan penting untuk konsumen dalam mendapatkan informasi mengenai kualitas suatu produk (Zhu, 2010). Hal tersebut sejalan dengan penelitian milik Aditya (2020) dengan hasil online customer review berhubungan signifikan terhadap keputusan pembelian melalui minat beli. Maka berarti dugaan minat beli dapat memediasi keputusan pembelian yang mana apabila konsumen memiliki minat beli yang tinggi maka keputusan pembelian pun juga meningkat.

H6 Diduga minat beli mampu menjadi mediasi variabel online customer review terhadap keputusan pembelian pada produk fashion di marketplace Shopee

Tagline adalah salah satu unsur yang penting karena berisi kalimat inti yang disusun dengan singkat tujuan komunikasi suatu produk dan dapat mempengaruhi penjulan suatu produk tersebut. Menurut Altsiel dalam Lily (2016) tujuan utama tagline yaitu untuk memperkuat merk suatu perusahaan. Pada penelitian milik Siti Roykhanah (2018) menghasilkan adanya pengaruh variabel tagline terhadap keputusan pembelian. Pada penelitian milik Dede (2020) yang memiliki hasil minat beli konsumen memiliki pengaruh signifikan terhadap keputusan pembelian. Dari penjabaran tersebut dapat diperoleh dugaan bahwa adanya pengaruh tagline terhadap keputusan pembelian melalui mediasi minat beli.

H7 Diduga minat beli mampu menjadi mediasi variabel tagline terhadap keputusan pembelian pada produk fashion di marketplace Shopee

\section{METODE PENELITIAN}

Metode penelitian yang digunakan yaitu penelitian kuantitatif. Dengan tempatnya di Surabaya, untuk menentukan sampel yang diambil, peneliti menggunakan teknik purposive random sampling. Menurut Sugiyono (2016), purposive random sampling merupakan teknik pengambilan suatu sampel berdasarkan pertimbangan tertentu, sehingga untuk respoden bersifat random karena siapapun seseorang yang memenuhi kriteria dapat dijadikan sebagai responden. Populasinya merupakan generasi muda Surabaya yang pernah membeli produk fashion di Shopee. Pengukuran sampel yang dipakai menggunakan rumus Supranto untuk sampel berjumlah 100 responden.

Sumber data yang digunakan yaitu data primer yang diperoleh dengan menyebarkan angket online melalui google form dengan jumlah 36 item pernyataan dengan link https://forms.gle/NTNcT5D2amqkbNXr8 dengan subyek generasi muda Surabaya yang merupakan pengguna Shopee serta pernah melakukan transaksi berbelanja produk fashion. Penggunaan uji instrumen yaitu uji validitas, realibilitas. Sedangkan untuk uji analisisnya meggunakan teknis analisis jalur (path analysis) dengan melakukan uji asumsi diantaranya : uji normalitas, uji multikolonieritas, uji heteroskedastisitas dengan bantuan SPSS versi 25. Berikut merupakan rancangan penelitian yang akan dilakukan : 


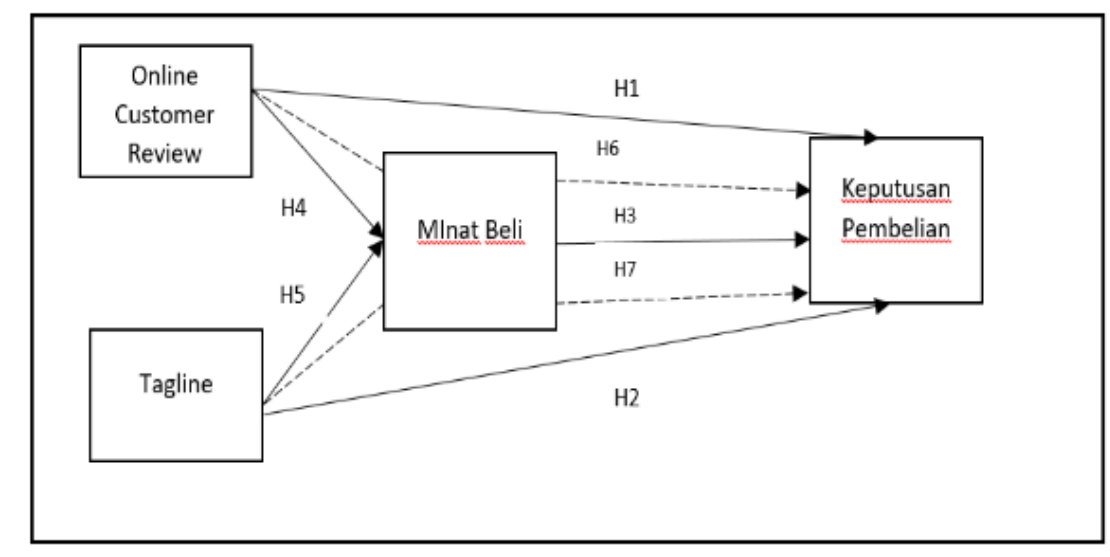

Gambar 1. Rancangan Penelitian

Keterangan :

Sumber: diolah oleh penulis (2021)

$\longrightarrow$ : Pengaruh Langsung

$---\bullet$ : Pengaruh Tidak Langsung

Uji validitas merupakan pengurukuran suatu data yang dilihat dari derajat ketepatan pada data. Data dapat dikatakan valid apabila nilai koefisiensi yang didapatkan adalah ( $\mathrm{r}$ hitung) $>$ dari ( $\mathrm{r}$ tabel) dan memiliki nilai positif yaitu dengan tingkat kepercayaan 95\% serta toleransi kesalahan 5\%. Dari hasil analisis data, uji validitas yang diperoleh pada 36 item pernyataan dengan nilai $r$ hitung $>r$ tabel $(0,195)$. Dengan nilai $r$ hitung paling rendah 0,437 dan nilai siq 0,000. Maka dapat dinyatakan bahwa 36 pernyataan atau seluruh pernyataan valid dan dapat digunakan dalam penelitian.

Uji reabilitas digunakan untuk menguji kestabilan jawaban responden dan merupakan suatu alat pengumpulan data yang menyatakan bahwa instrumen dapat dipercaya (Ghozali, 2016). Apabila jawaban responden konsisten maka suatu instrumen pernyataan dapat dikatakan reliabel. Uji realibilitas dilakukan dengan membandingkan koefisien alpha dan kuisioner dapat dianggap reliabel apabila nilai Cronbach's Alphalebih dari 0,6. Hasil uji realibilitas diperoleh seluruh variabel memiliki nilai Cronbach's Alpha> 0,6 yang menunjukkan jika seluruh variabel pada penelitian dinyatakan reliabel, maka semua item pernyataan dipercaya dan dapat digunakan untuk penelitian selanjutnya.

\section{Uji Asumsi Klasik}

\section{Uji Normalitas}

Berdasarkan uji analisis normalitas yang menggunakan bantuan SPSS versi 25 diperoleh hasil sebagai berikut : Pendekatan Kolmogrov

Uji normalitas digunakan untuk mendeteksi variabel pada penelitian berdistribusi normal atau tidak ( Ghozali, 2013). Pedoman yang digunakan adalah dengan melihat nilai sig melalui uji KolmogorovSmirnov. Data dapat dinyatakan normal jika memiliki nilai sig > 0,05. Dari hasil uji normalitas, diketahui bahwa pada persamaan 1 memiliki nilai sig sebesar $0,088>0,05$ dimana data pada penelitian ini terdistribusi secara normal. Pada persamaan 2 memiliki nilai sig sebesar 0,200>0,05 yang menunjukkan bahwa data terdistribusi secara normal. Uji

\section{Multikolinieritas}

Menurut Ghozali (2013) uji multikolonieritas bertujuan untuk menguji adanya korelasi antar variabel dependen. Model uji regresi yang baik yaitu data dengan tidak ada multikolonieritas yang memiliki syarat nilai VIF < 10 (Wijaya, 2013). Dari hasil uji multikolonieritas diketahui 
seluruh variabel memiliki nilai tolerance $>0,10$ dan nilai VIF $<10$ yang berarti semua variabel tidak terjadi gejala multikolonieritas.

\section{Uji Heteroskedastisitas}

Uji heteroskedisitas digunakan untuk mengetahui apakah ada ketidaksamaan varian dari residual satu pengamatan ke pengamatan lain (Ghozali, 2013). Hasil uji yang baik yaitu model dengan hasil tidak terjadi heteroskedastisitas. Dari hasil uji heteroskedatisitas dapat diketahui bahwa titik menyebar dengan acak dan tidak membentuk pola tertentu, selain itu titik juga menyebar di atas maupun di bawah angka 0 pada sumbu Y, sehingga dapat disimpulkan bahwa persamaan 1 dan 2 tidak terjadi heteroskedastisitas.

\section{Regresi Liner Berganda}

\section{Uji Koefisien Korelasi $(R)$}

Uji koefisien korelasi bertujuan untuk mendeteksi apakah terdapat hubungan antara 2 variabel, memiliki hubungan yang signifikan atau tidak.

Persamaan hasil analisis yang terbentuk adalah:

$\mathrm{Y}=7,327+0,211+0,102$

1. Nilai konstanta sebesar 7,327diinterpretasikan apabila online customer review dan tagline tidak ada atau tetap atau tidak berubah maka minat beli akan tetap terjadi

2. Nilai koefisien beta 0,211 (positif) menunjukkan adanya pengaruh yang searah, artinya apabila online customer reviewsemakin baik atau meningkat maka minat beli juga akan meningkat

3. Nilai koefisien beta 0,102 (Positif) menunjukkan pengaruh yang searah, artinya apabila tagline semakin baik atau meningkat maka minat beli juga akan meningkat

Persamaan hasil analisis yang dihasilkan yaitu:

$\mathrm{Y}=28,011+0,201-0,201+0,354$

1. Nilai konstanta sebesar 28,011 diinterpretasikan apabila online customer review, tagline dan minat beli tidak ada atau tetap atau tidak berubah maka keputusan pembelian tetap akan terjadi

2. Nilai koefisien beta variabel X1 0,201 (positif) menunjukkan adanya pengaruh yang searah, artinya apabila online customer review semakin baik atau bertambah maka keputusan pembelian juga akan meningkat

3. Nilai koefisien beta variabel X2 0,201 (negatif) artinya apabila tagline semakin buruk maka keputusan pembelian juga akan berkurang

4. Nilai koefisien beta variabel Z 0,354 (Positif) menunjukkan pengaruh yang searah, artinya apabila minat beli semakin baik atau meningkat maka keputusan pembelian juga akan meningkat

\section{Uji Koefisien Determinasi Berganda (R2)}

Uji koefisisen determinasi berganda dilakukan guna mengetahui presentase antara variabel independen dengan variabel dependen. Apabila nilai R2 mendekati dari 0 maka semakin kecil pengaruhnya, namun jika nilai R2 mendekati nilai 1 maka semakin besar pengaruhnya. Dari hasil uji koefisien determinasi berganda persamaan 1 memiliki nilai RSquare 0,318 berarti 31,8 $\%$ dari variabel minat beli dipengaruhi oleh variabel online customer review dan tagline sedangkan sisanya 68,2 \% dipengaruhi oleh variabel lain. Kemudian pada persamaan 2 memiliki nilai RSquare 0,302 berarti 30,2 \% dari variabel keputusan pembelian dipengaruhi oleh online customer review, tagline, dan minat beli dan sisanya 69,8\% dipengaruhi oleh variabel lain. 


\section{Uji Analisis Jalur (Path Analysis)}

Path analysis digunakan untuk menguji variabel intervening atau hubungan variabel yang lebih dari dua (Ghozali, 2013). Path analysis atau analisis jalur ini berguna untuk menguji kontribusi di antara koefisien pada setiap jalur dan juga hubungan kausal antar variabel.

Persamaan jalur tahap pertama diperoleh :

$\mathrm{Y}=0,211 \mathrm{X} 1+0,102 \mathrm{X} 2+0,825$

Persamaan jalur tahap pertama diperoleh :

$\mathrm{Z}=0,201 \mathrm{X} 1-0,201 \mathrm{X} 2+0,354 \mathrm{Y}+0,835$

Maka dapat diketahui, full model analisis jalur adalah sebagai berikut:

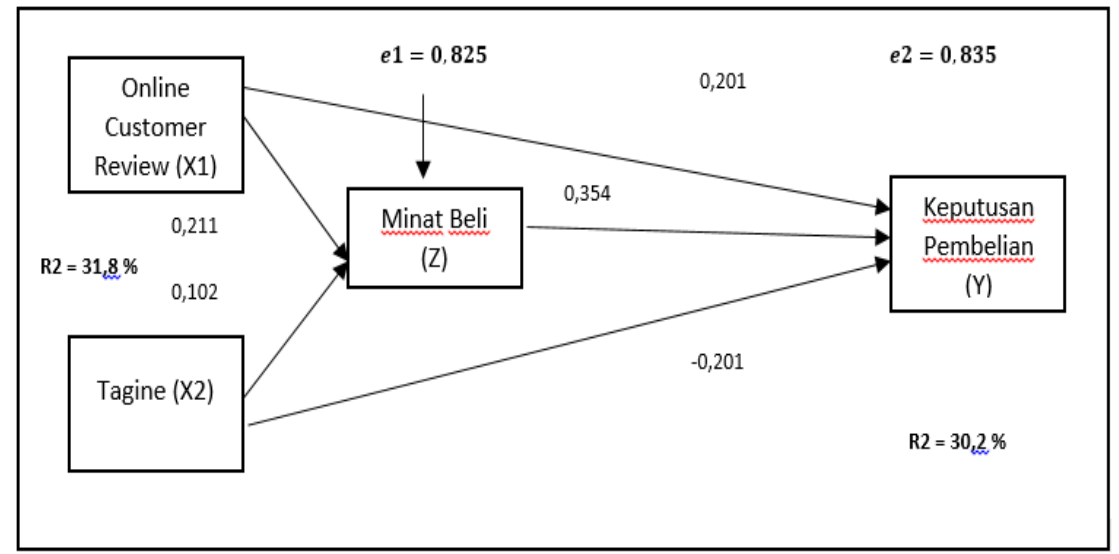

Gambar 2. Hasil Analisis Jalur Sempurna

\section{Uji F}

(Sumber: Diolah Peneliti, 2021)

Uji f digunakan untuk menguji substruktur yang digunakan signifikan atau tidak sehingga dapat digunakan untuk memprediksi pengaruh variabel bebas. Dari hasil uji F didapatkan hasil persamaan 1 dan 2 dengan nilai signifikansi < $(0,05)$, sehingga dapat dinyatakan variabel online customer review dan tagline telah tepat untuk dapat menjelaskan variabel minat beli. Kemudian pada persamaan 2 dapat disimpulkan bahwa online customer review, tagline dan minat beli telah tepat untuk menjelaskan minat beli.

\section{Uji Hipotesis (Uji T)}

Uji t dilakukan guna mengetahui besar variabel independen terhadap variabel dependen (Ghozali, 2013). Dengan nilai signifikansi < 5\% maka Ha diterima dan H0 ditolak yang menghasilkan variabel independen berpengaruh terhadap variabel dependen.

Dari hasil uji tabel yang sudah diolah peneliti dapat disimpulkan dan dijelaskan sebagai berikut:

Pada pengujian hipotesis 1 dapat disimpulkan bahwa bahwa terdapat pengaruh online customer review terhadap minat beli, hasil (Uji T) pengaruh $\mathrm{X} 1 \mathrm{ke} \mathrm{Z}$ dengan nilai koefisien positif sebesar 0,211 dan nilai signifikan 0,040. Dengan nilai signifikan 0,040 <nilai signifikasi kritis 0,05 maka H0 ditolak dan Ha diterima, maka hipotesis 1 diterima dan mendapat dukungan dalam penelitian ini.

Pada pengujian hipotesis 2 menyimpulkan bahwa terdapat pengaruh tagline terhadap minat beli, hasil (Uji T) pengaruh $\mathrm{X} 2 \mathrm{ke} \mathrm{Z}$ menghasilkan nilai koefisien positif 0,102 dan nilai signifikan 0,318. Dengan nilai signifikan 0,318 >nilai signifikasi kritis 0,05 maka dianggap tidak signifikan $\mathrm{H} 0$ diterima dan Ha ditolakmaka hipotesis 2 tidakdidukung dalam penelitian ini.

Pada pengujian hipotesis 3 menyimpulkan bahwa minat beli berpengaruh terhadap keputusan pembelian, hasil (Uji T) pengaruh Z ke Ymemiliki nilai koefisien positif 0,354 dan 
nilai signifikan 0,000. Karena nilai signifikan $0,000<$ nilai signifikasi kritis 0,05 maka H0 ditolak dan Ha diterima maka hipotesis 3 diterima dan mendapat dukungan dalam penelitian ini.

Pada pengujian hipotesis 4 disimpulkan bahwa terdapat pengaruh online customer review terhadap keputusan pembelian, berdasarkan hasil (Uji $\mathrm{T}$ ) pengaruh $\mathrm{X} 1 \mathrm{ke} \mathrm{Y}$ menghasilkan nilai koefisien positif sebesar 0,201 dan nilai signifikan sebesar 0,039. Oleh karena nilai signifikan 0,039 <nilai signifikasi kritis 0,05 maka $\mathrm{H} 0$ ditolak dan Ha diterima maka hipotesis 4 diterima dan mendapat dukungan dalam penelitian ini.

Pada pengujian hipotesis 5 dapat disimpulkan bahwa terdapat pengaruh negatif signifikan tagline terhadap keputusan pembelian, hasil pengujian hipetesis (Uji T) pengaruh X2 ke Ymemiliki nilai koefisien negatif sebesar 0,201 dan nilai signifikan sebesar 0,036. Oleh karena nilai signifikan 0,036 <nilai signifikasi kritis 0,05 maka H0 ditolak dan Ha diterima dengan demikian, Hipotesis 5 diterima dan mendapat dukungan dalam penelitian ini.

Pada pengujian hipotesis 6 disimpulkan bahwa hasil sobel test menunjukkan nilai $\mathrm{z}$ value sebesar $1,030<\mathrm{z}$ mutlak $(1,96)$. Jadi dari hasil tersebut dapat dinyatakan bahwa variabel minat beli tidak bisa memediasi online customer review terhadap keputusan pembelian, namun total pengaruh tidak langsung pada online customer review terhadap keputusan pembelian melalui minat beli diperoleh sebesar 0,275 dan nilai koefisien jalur pengaruh langsung online customer review terhadap keputusan pembelian diperoleh sebesar 0,201. Hasil tersebut menunjukkan bahwa 0,275 lebih besar dari koefisien jalur langsung sebesar 0,201 yang dinyatakan bahwa minat beli mampu memediasi secara parsial online customer review terhadap keputusan pembelian, sehingga $\mathrm{HO}$ ditolak dan Ha diterima, maka hipotesis 6 diterima dan didukung pada penelitian ini.

Pada pengujian hipotesis 7 dapat diketahui bahwa hasil sobel test memiliki nilai $\mathrm{z}$ value sebesar $0,966<\mathrm{z}$ mutlak $(1,96)$. Jadi dari hasil tersebut variabel minat beli tidak dapat memediasi hubungan antara tagline terhadap variabel keputusan pembelian, namun total pengaruh tidak langsung pada variabel tagline terhadap keputusan pembelian melalui minat beli diperoleh sebesar 0,237 dan nilai koefisien jalur pengaruh langsung tagline terhadap keputusan pembelian diperoleh sebesar - 0,201. Hasil tersebut menunjukkan bahwa 0,275> 0,201 yang menunjukkan bahwa minat beli mampu memediasi secara parsial tagline terhadap keputusan pembelian, sehingga $\mathrm{H} 0$ ditolak dan Ha diterima dan dapat disimpulkan hipotesis 7 diterima dan didukung pada penelitian ini.

\section{Pengaruh Online Customer Review terhadap Minat Beli}

Adanya pengaruh positif signifikan online customer reviewpada minat beli. Maka semakin baik online customer review yang dimiliki oleh seller pada marketplace di Shopee maka diikuti dengan meningkatnya minat beli yang dilakukan oleh konsumen untuk memiliki suatu barang tertentu.

\section{Pengaruh Taglineterhadap Minat Beli}

Tagline memiliki pengaruh positif dan tidak signifikan terhadap minat beli, hal tersebut dikarenakan tagline dapat mempengaruhi untuk menimbulkan minat beli pada konsumen. Jika tagline disampaikan dengan baik dan benar maka dapat mempengaruhi minat beli pada konsumen, sehingga tagline "Gratis Ongkir Se - Indonesia" yang dimiliki oleh Shopee belum mampu menimbulkan minat beli pada kosumen. Hal tersebut dikarenakan tagline shopee kurang masuk di benak konsumen sehingga tidak memunculkan minat beli.

\section{Pengaruh Minat Beli terhadap Keputusan Pembelian}

Adanya pengaruh positif dan signifikan minat beli terhadap keputusan pembelian yang artinya 
jika minat beli ditingkatkan maka keputusan pembelian juga meningkat. Apabila minat beli yang tinggi pada produk fashion di marketplace Shopee maka konsumen akan berusaha untuk membeli produk tersebut. Hasil pada penelitian ini sefrekuensi pada penelitian milik Ady (2019) dan Nurul (2020) yang menyatakan minat beli berpengaruh terhadap keputusan pembelian.

\section{Pengaruh online customer review terhadap Keputusan Pembelian}

Adanya pengaruh positif signifikan Online customer review terhadap keputusan pembelian. Hal tersebut menunjukkan bahwa online customer review baik maka akan menimbulkan keputusan pembelian. Konsumen cenderung percaya kepada ulasan orang lain yang memiliki pengalaman pernah berbelanja produk fashion di Shopee.

\section{Pengaruh Taglineterhadap Keputusan Pembelian}

Tagline memiliki pengaruh negatif dan signifikan terhadap keputusan pembelian produk fashion di Shopee dikarenakan tagline harus mampu mengkuti perkembangan yang berjalan sehingga tagline dapat beriringan dengan trend yang ada dan karena gratis ongkir yang diberikan Shopee hanya beberapa toko tertentu saja dan terdapat minimal order untuk dapat menggunakan voucher gratis ongkir. Dengan hal tersebut maka konsumen beranggapan bahwa tagline "Gratis Ongkir Se - Indonesia" yang dimiliki Shopee masih belum tepat.

\section{Pengaruh Online Customer Review terhadap Keputusan Pembelian melalui Minat Beli}

Minat beli dapat memediasi online customer review terhadap keputusan pembelian. Hal ini berarti konsumen akan membeli produk jika online customer review di toko produk fashion pada marketplace Shopee banyak yang memiliki review positif. Hasil penelitian ini sejalan dengan penelitian milik Aditya (2020) bahwa online customer review memiliki hubungan yang signifikan terhadap keputusan pembelian dan juga minat beli sebagai variabel intervening.

\section{Pengaruh Tagline terhadap Keputusan Pembelian melalui Minat Beli}

Berdasarkan pengujian hasil analisis jalur, dihasilkan minat beli dapat memediasi tagline terhadap keputusan pembelian. Maka jika Shopee memiliki tagline yang baik dan tepat maka konsumen akan tertarik membeli produk fashion di Shopee. Pernyataan tersebut sejalan dengan penelitian milik Siti Roykhanah (2018) menghasilkan adanya pengaruh tagline terhadap keputusan pembelian.

\section{KESIMPULAN}

Berdasarkan hasil data yang diperoleh, pengaruh variabel online customer review pada minat beli dipengaruhi secara signifikan dan positif, pengaruh variabel tagline pada minat beli dipengaruhi secara signifikan dan positif, kemudian online customer review berpengaruh positif signifikan terhadap keputusan pembelian, taglinememiliki pengaruh signifikan negatif terhadap keputusan pembelian, adanya pengaruh secara tidak langsung online customer review terhadap keputusan pembelian melalui minat beli dan adanya pengaruh secara tidak langsung taglineterhadap keputusan pembelian melalui minat beli.

Berdasarkan pada penjabaran di atas maka bagi perusahaan Shopee lebih ditingkatkan lagi sistemnya sehingga konsumen dibuat merasa nyaman saat berbelanja di Shopee dan lebih memperhatikan tagline yang dimiliki karena dapat mempengaruhi penggunaan marketplace Shopee. Penyusunan tagline bisa berjalan mengikuti dengan perkembangan yang terus berjalan sehingga dapat menyesuaikan keadaan. 


\section{DAFTAR PUSTAKA}

Abiromo, B. 2014. Pengaruh Taglien dan Brand Ambassador terhadap Brand Awareness Produk Perdana Simpati: Studi Kasus Pada Mahasiswa Fakultas Ekonomi Universitas Negeri Yogyakarta. Skripsi. Program Studi Manajemen Universitas Negeri Yogyakarta. Yogyakarta.

Ahmad Farki, Imam Baihaqi, dan Berto Mulia Wibawa. (2016). Pengaruh Online Customer Review dan Rating Terhadap Kepercayaan dan Minat Pembelian pada Online Marketplace di Indonesia. Jurnal Teknis Institut Teknologi Surabaya, 5 (2): 2301-9271.

Arli, D., Tjiptono, F., \& Porto, R. (2015). The Impact of Moral Equity, Relativis and attitude on individuals' digital piracy behaviour in a developing country. Marketing Intelligence \& Planning.

Chaidir, M. (2018). Pengaruh Tagline Iklan Yamaha "Semakin Di Depan" terhadap Kesadaran Merek pada masyarakat Kecamatan Samarinda Ulu di kota Samarinda. eJournal Ilmu Komunikasi Volume 6 No 1, 391-402.

Damayanti, R. S. (2019). Pengaruh Ulasan konsumen and Rating, E-Service Quality, dan Price Terhadap Minat Beli pada Online Marketplace Shopee (Studi Empiris pada Mahasiswa Universitas Muhammadiyah Magelang). Prosiding 2nd Business and Economics Conference in Utilizing of Modern.

Dhaneswara, V. A. (2019). Pengaruh Tagline “ Gratis Ongkir” Shopee Terhadap Keputusan Berbelanja Online Pada Masyarakat (Studi Pada Masyarakat Kota Bandar Lampung).

Fradipta, I. C. (2017). Pengaruh Iklan Internet dan Kelompok Referensi terhadap Niat Beli Produk Smartphone Xiaomi.

Hartanto, A. B. (2020). Analisis Pengaruh Merek Islam, Ulasan Konsumen, dan Harga Terhadap Keputusan Pembelian di Shopee Dengan Minat Beli Sebagai Variabel Intervening.

Imam Ghozali. (2013). Aplikasi Analisis Multivariate Dengan Program SPSS. Semarang: Badan Penerbit Universitas Diponegoro

Khalid, R. 2017. Effect of Advertising Slogans on Consumer Purchase Intention in Pakistan, J. Basic. Appl. Sci. Res., 7(4): 25-33

Kotler, P., \& Pfeoertsch, W. (2006). B2B brand management, Springer Science \& Business Media

Mo, Z. L. Y. \& Fan, P. (2015). Effect of Onlie Reviws on Consumer Purchase Behavior. Journal of Service Science and Management, 8(June), 419-424.

Penitasari, N. (2017). Pengaruh Harga dan Kualitas Produk terhadap Minat Beli Abon Lele Bang Zay (Studi pada Konsumen Abon Lele Bang Zy di Kota Malang). Thesis. University of Muhammadiyah Malang.

Putri, L \& Wandebori, H. (2016). Factor Influencing Cosmetics Purchase Intention in Indonesia Based on Online Review, ICEBESS Proceeding, 255-263.

Rahardian, M., Kusumawati, A., \& Irawan, A. (2019). Pengaruh Tagline Iklan dan Celebrity Endorser terhadap Brand Awareness dan Minat Beli ( Survei pada Mahasiswa program Sarjana pengguna Smartphone OPPO F3 Plus di Universitas Brawijaya). Jurnal Administrasi Bisnis, 75(1), 10-18.

Roykhanah, S. 2018. Pengaruh Tagline ShopeeTerhadap Keputusan Pembelian Pada Mahasiswa Ilmu Komunikasi UIN Sunan Ampel Surabaya. Skripsi. Fakultas Dakwah dan Komunikasi. Universitas Islam Negeri Sunan Ampel Surabaya

Saputri, M. E. (2016). Pengaruh perilaku konsumen terhadap pembelian. Jurnal Sosioteknologi, 15 
Schiffman, L. G., \& Kanuk, L. (2015). Consumer behavior: Global edition. Harlow: Pearson education.

Solihin, D. (2002). Pengaruh Kperecyaan Pelanggan dan Promosi Terhadap Keputusan Pembelian Konsumen Pada Online Shop Mikaylaku Dengan Minat Beli Sebagai Variabel Intervening. Jurnal Mandiri: Ilmu Pengetahuan, Seni, dan Teknologi, 4(1), 38-51.

Sugiyono, P. D. (2016) metode penelitian kuantitatif, kualitatif,dan R\&D. , Alfabeta, cv.

Suhari, Y. (2008). Keputusan Pembelian Secara Online dan Faktor - Faktor yang Mempengaruhinya. Teknologi Informasi DIAMIK, 8(2), 140-146. https://www.uinsbank.ac.id/ojs/index.php/fti1/article/view.79/74

Sukron, A. R. M. (2019). Pengaruh Kemudahan Penggunaan, Islamic Branding dan E- Service Quality Terhadap Keputusan Pembelian di Tokopedia Dengan Minat Beli Sebagai Variabel Intervening (Doctoral dissertation, IAIN SALATIGA).

Syairozi, M. I. (2021). Analisis Kemiskinan di Sektor Pertanian (Studi Kasus Komoditas Padi di Kabupaten Malang). Media Ekonomi, 28(2), 113-128.

Tussafinah, H. (2018). Pengaruh Rating dan Ulasan Jaminan 100\% Pengembalian dan Layanan COD atau Bayar di Tempat Terhadap Keputusan Pembelian Lazada: studi kasus Mahasiswa Fakultas Ekonomidan Bisnis Islam UIN Walisongo Semarang ( Doctoral dissertation, UIN Walisongo Semarang).

Ulfah, N. C. (2020). Pengaruh Muslimah Endorser, Kualitas Produk dan Islamic Advertising Ethics Terhadap Keputusan Pembelian Dengan Mint Beli Sebagai Variabel Intervening.

Wang, F., Liu, X. \& Fang, E. (Er), 2015. User Reviews Variance, Critic Reviews Variance, and Product Sales: An Exploration of Customer Breadth and Depth Effects. Journal of Retailing, 91(3), pp.372- 389. Available at: http://www.sciencedirect.com/science/article/ pii/ S0022435915000482.

Widiarti, A. \& Yulia. A. (2019). Pengaruh Reviews Online Terhadap Minat Beli pada Aplikasi Shopee Melalui Kebutuhan Kognisi (Survei pada Sekolah Menengah Kejuruan GAMA Tangerang). JIPIS, Vol. 28, No. 2.

Website resmi databoks.katadata.co.id pada laman "Pengunjung Situs Shopee Terbesar di Indonesia" https ://databoks.katadata.co.id diakses 06 Juli 2020

Website resmi kompas.com pada laman "Jangan Tertukar, Ini Pengertian Generasi X,Z Milenial, dan Baby Boomers" https ://kompas.com diakses 17 April 2021

Website resmi Validnews pada laman "Pengguna Internet Indonesia 2020" https://validnews.id/ diakses 21 September 2020

Wijaya, T. (2013). Metodologi Penelitian Ekonomi dan Bisnis. Yogyakarta: Graha Ilmu

Zhu, Feng \& Zhang, X. 2010. Impact of Online Consumer Reviews on Sales : The Moderating Role of Product and Consumer Characteristics. Journal of Marketing, 74. 133-148 